\title{
En mann i 40-årene med diabetes, forstørret tårekjertel og nyresvikt
}

\author{
En diabetiker i 40-årene med ulcerøs kolitt utviklet forstørrede tåre- \\ kjertler, nyresvikt og bilaterale lungeforandringer. Det viste seg at han \\ hadde en diagnose som er en fellesnevner for flere tilstander som lenge \\ har vært uforklart.
}

En mann i 40-årene ble innlagt på gastromedisinsk sengepost etter fire ukers sykehistorie med kvalme, oppkast, vekttap og slapphet. Syvår tidligere hadde han fått diagnosene ulcerøs kolitt, subakutt tyreoiditt og dyp venetrombose. Han var overvektig og fikk påvist type 2-diabetes fire år senere. Det påfølgende året ble det startet med behandling på grunn av hypertensjon. To år før aktuelle innleggelse ble pasienten vurdert på øyeavdelingen ved et annet sykehus på grunn av en svulst temporalt i konjunktiva og ipsilateral ptose. Det ble da utført CT-undersøkelse av begge orbitahuler som viste betydelig ekspansjon av glandula lacrimalis bilateralt, mest uttalt på høyre side. Man konkluderte med akutt dakryoadenitt (inflammatorisk forstørret tårekjertel), enten av viral genese eller som ledd $i$ en idiopatisk orbital inflammatorisk sykdom.

Når pasienter blir innlagt i sykehus, er det viktig å ta hensyn til eventuelle tidligere sykdommer. Dette kan virke selvsagt, men grundig journalgjennomgang kan gi informasjon om sykdommer som kan være beslektede eller gi hint om en fellesnevner. Diabetes mellitus, hypertensjon og adipositas er tilstander som ofte påvises samtidig (1), men som sjelden gir mistanke om en uvanlig medisinsk tilstand. Når det påvises inflammatorisk sykdom i tarm, skjoldbruskkjertel og tårekjertel hos samme pasient, kan det være grunn til å lete etter én diagnose som forener dem alle $(2,3)$.

Da han ble innlagt igastromedisinsk avdeling, hadde han lavt blodtrykk $(98 / 65 \mathrm{~mm} \mathrm{Hg})$ og takykardi (puls 102/minutt). Klinisk undersøkelse var upåfallende med unntak av lette knatrelyder over lungene basalt. Blodprøvene viste kreatinin på 410 umol/l (60-105), senkningsreaksjon (SR) på $98 \mathrm{~mm} / \mathrm{t}(<20)$, totalkalsium på 2,54 mmol/l $(2,15-2,51)$ og kalium på $5,4 \mathrm{mmol} / \mathrm{l}(3,6-5,0)$. CRP var lav, $5 \mathrm{mg} / \mathrm{l}$ (< 1), men han hadde et forhøyet nivå av hvite blodceller på 10,9 $10^{9} / 1(3,5-8,8)$ og eosinofile blodceller på 0,96:10\%/l (0,03-0,50). Albumin var normal, $37 \mathrm{~g} / \mathrm{l}(36-45)$. EKG viste sinustakykardi på $104 \mathrm{slag} /$ minutt. Han ble vurdert som dehydrert, og hans nyresvikt ble oppfattet som prerenalt betinget. Han brukte metformin 2500 mg daglig og ACE-hemmer, ramipril $10 \mathrm{mg}$ daglig, og disse ble begge nullet. På arteriell blodgass var laktat 1,8 mmol/l $(0,4-0,8)$ og $\mathrm{pH} 7,34(7,35-7,45)$. Han fikk intravenøs væske og ble klinisk bedre.

Ved utskrivning hadde kreatininnivået falt til $209 \mu \mathrm{mol} / \mathrm{l}$. Fordi pasienten hadde hatt normalt kreatininnivå på 90 seks måneder før denne innleggelsen ble hans nyresvikt oppfattet som akutt. Ved serumelektroferese ble det ikke påvist M-komponent, men man så en $ø k t$ og litt ujevn gammasone, forenlig med polyoligoklonal gammaøkning. Nivåene av lgA og lgM var normale, men IgG-nivået var forhøyet på 33,6 g/l (6,1-14,9). Avføringsprøve påviste positivt norovirus RNA PCR. Pasienten oppga et vekttap på cirka $15 \mathrm{~kg}$ i løpet av noen måneder, og hadde rett før innleggelsen vært til CT-undersøkelse av thorax og abdomen ved et privat røntgeninstitutt, rekvirert av fastlegen. Svaret på CT-undersøkelsen var ikke ferdig da pasienten ble utskrevet.

Prerenal nyresvikt ses hyppig i sykehus (4). Vanlige årsaker er infeksjoner, dehydrering, blodtrykksfall og ugunstig effekt av medikamenter. Ikke sjelden ser man en kombinasjon av disse faktorene. Man bør være spesielt oppmerksom på blodtrykkssenkende preparater som ACE-hemmere eller angiotensin IIblokkere (5). Ved moderat til alvorlig nyresvikt bør man vurdere om behandling med metformin skal avsluttes på grunn av risikoen for å utvikle metforminassosiert laktacidose, en tilstand med høy mortalitet (6).

17 dager senere ble pasienten igjen innlagt, denne gangen på lungemedisinsk utredningspost. Årsaken til denne innleggelsen var at CT thorax viste bilaterale fortetninger med mattglasspreg, i tillegg til konsoliderende fortetninger, mest uttalt posteriørt i høyre overlapp og basalt i høyre underlapp (fig 1). Spirometri viste lett redusert vitalkapasitet, FVC 4,23 (82\% av forventet). I blodprøvene var hvite blodceller på 9,7 $10^{9} /$, eosinofile blodceller hadde steget til $1,07 \cdot 10^{9} / \mathrm{l}$, og SR var uendret. CRP var $23 \mathrm{mg} / \mathrm{l}$. Albuminkorrigert kalsium var forhøyet, 2,72 mmol/l (2,17-2,47), og kreatininnivået hadde steget til $266 \mu \mathrm{mol} / \mathrm{l}$. På
Geir Christian Enli Mordal

Geir.Christian.E.Mordal@ahus.no Nyremedisinsk avdeling Akershus universitetssykehus

Clara Hammarström Avdeling for patologi Oslo universitetssykehus, Rikshospitalet

\section{Tina Namtvedt}

Nyremedisinsk avdeling

Akershus universitetssykehus 
grunn av følgende funn med forverret nyresvikt, hyperkalsemi og lungeforandringer ble det rekvirert diverse utredningsprøver: komplement C3 og C4, ANA- og ANCA-screening, revmatoid faktor (RF) og angiotensinkonvertasehemmer (ACE).

Dagen etter ble pasienten bronkoskopert med funn av en lett ødematøs slimhinne og noe mukøst slim, men uten fokal patologi. Det ble tatt skyllevæske til mikrobiologi og slimhinnebiopsi fra høyre lunge, der man hadde sett de mest uttalte forandringene. CT-undersøkelsen av abdomen var tilnærmet normal og uten patologiske funn i nyrene.

Ved høy senkningsreaksjon (SR) og ledsagende symptomer som nevnt ovenfor, som gir mistanke om alvorlig sykdom, bør man blant annet undersøke om pasienten kan ha polymyalgia rheumatica (PMR) eller en malign tilstand som myelomatose, lymfom eller nyrekreft $(7,8)$. Monoklonal komponent forelå ikke hos vår pasient - snarere så man polyoligoklonal gammaøkning med forhøyet IgG. CT-undersøkelse utelukket malignitet $i$ lunger og nyrer. Han hadde ikke symptomer som ved polymyalgia rheumatica, og nivået av hvite blodceller i blodet var ikke forenlig med lymfom. På grunn av påviste lungeinfiltrater og hyperkalsemi ble det tatt ACE med tanke på sarkoidose.

Eosinofili bør også utredes og kan blant annet ses ved allergier, medikamentreaksjoner, eosinofil pneumoni, eosinofil leukemi, bronkopulmonal aspergillose, eosinofil granulomatose med polyangitt (tidligere kalt ChurgStrauss' syndrom) og parasittsykdommer (9).

Det ble under oppholdet raskt tatt kontakt med nefrolog på grunn av manglende bedring av nyrefunksjonen. Nefrolog mistenkte vaskulitt. C3 og C4 var begge lave, henholdsvis på $0,43 \mathrm{~g} / \mathrm{l}(0,90-1,8)$ og $<0,02 \mathrm{~g} / \mathrm{l}(0,10-0,40)$. Det ble bestilt ultralydveiledet nyrebiopsi og antistoffer mot glomerulær basalmembran (anti-GBM) (fig 2). Urinundersøkelse med stiks viste +1 på protein, og mikroskopisk undersøkelse var normal, med unntak av enkelte oksalatkrystaller. I urinen målte man protein/kreatinin-ratio på $61,4 \mathrm{mg} / \mathrm{mmol}$ (0-30) og albumin/kreatininratio på $4,1 \mathrm{mg} /$ mmol (0-3). ANA og ANCA var negative, og ACE var normal. Negativ ANCA talte imot granulomatose med polyangitt ltidligere kalt Wegeners granulomatose), noe som ble vurdert som differensialdiagnose. Pasienten ble overflyttet til nyremedisinsk avdeling, og to dager etter at han ble innlagt ble det utført nyrebiopsi.

Nyrebiopsi som ledd i utredning av nyresvikt er forbeholdt tilstander der man antar at svaret vil få konsekvenser for behandlingen. Typiske indikasjoner er nefrittiske eller nefrotiske syndromer, raskt progredierende glomerulonefritt eller vaskulitter, i tillegg til situasjoner hvor man for eksempel mistenker en diabetesnefropati, men proteinurien er uttalt, og/eller retinopati er fraværende (10).

Vår pasient hadde proteinuri tilsvarende $0,6 \mathrm{~g} /$ døgn og normal albumin i serum, og ingen andre tegn til verken nefrotisk eller nefrittisk syndrom. Lave komplementverdier kan ses ved økt forbruk, manglende syntese ved leversvikt, glomerulonefritter (for eksempel systemisk lupus erythematosus) og infeksjoner (11).

Foreløpig svar på nyrebiopsien, basert på lysmikroskopi, kom samme dag som biopsien ble tatt. Man så en akutt tubulointerstitiell nefritt med eosinofili og plasmaceller. Interstitiell betennelse kan også ses som ledd $i$ vaskulittassosiert glomerulonefritt og antiGBM-sykdom (Goodpastures syndrom). Ved disse tilstandene ses typisk aktive segmentale glomerulære lesjoner i form av cellulære/fibrocellulære halvmåner eller fibrinoide nekroser. I dette tilfellet var det kun tre glomeruli i preparatet, hvorav én var helt sklerosert. De to ånne var normale uten halvmåner eller nekroser. På grunn av få glomeruli kunne man ut fra biopsifunnet imidlertid ikke helt utelukke ANCA-assosiert glomerulonefritt eller anti-GBM-sykdom, da disse tilstandene vanligvis ikke affiserer alle glomeruli. Det ble derfor startet med prednisolon per oralt, $60 \mathrm{mg}$ daglig. RF-lgM ble besvart med markant forhøyet verdi, 200 IU/ $m l$ (positiv når > 5 og negativ når <3,5). ACE var 1 u/l (18-65) og anti-GBM negativ, noe som talte mot henholdsvis sarkoidose og Goodpastures syndrom. Det var ingen vekst $i$ bronkialskyllevæsken, og cytologisk undersøkelse var normal. Biopsien av bronkialslimhinnen viste kronisk betennelse og eosinofili. Pasienten ble klinisk bedre, spesielt oppfattet han at det var lettere å puste. Seks dager etter oppstart av prednisolon ble han skrevet ut, og kreatininnivået hadde da falt til $157 \mu \mathrm{mol} / \mathrm{l}$.

Eosinofili kan blant annet ses ved medikamentelt utløst nefritt (9). Imidlertid vil tilstanden oftest gå tilbake etter at det aktuelle medikamentet blir seponert (12).

Pasientens biopsi (fig 2) og sykehistorie ble diskutert med patolog på biopsimøte noen dager etter utskrivningen. Med flere organmanifestasjoner og et forhøyet nivå av $\lg G$ serum kunne man mistenke IgG4-relatert sykdom. Vi tok derfor pasienten tilbake for subklassifisering av lgG i plasma.

Tre uker etter utskrivningen ble nyrebiopsien endelig vurdert, basert på tilleggsopplysninger fra immunfluorescens (IF) og elektronmikroskopi (EM). Man fant tubulointerstitiell

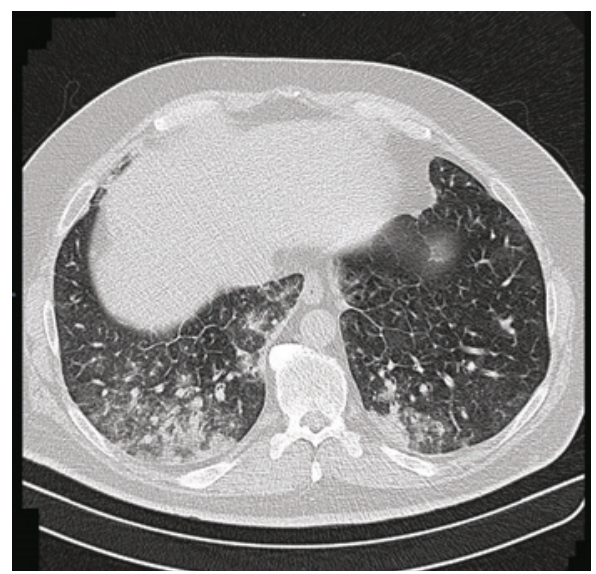

Figur 1 CT thorax tatt prehospitalt viser fortykkede intralobulære septa, diffuse mattglassfortetninger og nodulære konsoliderte lungefortetninger

nefritt med eosinofili og økt mengde lgG4positive plasmaceller med opptil 100 lgG4positive plasmaceller/40 $\times$ synsfelt (hpf) eller lgG4/lgG-ratio på $45 \%$. Patolog mente at IgG4-relatert sykdom var sannsynlig. Dagen etter ble det bekreftet at $p$-lgG4-subklasse var kraftig forhøyet med 9,300 $\mathrm{g} / \mathrm{l}(0,03-2,010)$. $\emptyset$ vrige subklasservar normale, med unntak av lgG3, som var på 0,98 g/l (0,11-0,85).

Ved kontroll syv uker etter oppstart av prednisolon hadde kreatininnivået falt til 114 umol/l og lgG4 til 3,790 g/l. Prednisolon ble trappet ned til $20 \mathrm{mg}$ daglig, og ved ny kontroll to måneder senere hadde pasienten gått opp $11 \mathrm{~kg}$ i vekt og hadde tung pust i hvile. Pasienten hadde fått en forverring av sin tilstand, og dosen med prednisolon ble doblet. Det ble supplert med azatioprin, men pasienten måtte slutte med dette på grunn bivirkninger (kvalme og oppkast). Han ble imidlertid bedre etter doseøkningen. Han har nå startet med mykofenolatmofetil i dose $500 \mathrm{mg} \times 2$.

\section{Diskusjon}

IgG4-relatert sykdom er en systemisk immunmediert tilstand som ble anerkjent så sent som i 2003 (2). Andre navn som brukes om tilstanden er IgG4-relatert skleroserende sykdom, IgG4-related multiorgan lymphoproliferative syndrome og IgG4-relatert autoimmun sykdom (13).

Kamisawa og medarbeidere (14) biopserte affiserte organer og utførte også immunhistokjemiske analyser på pasienter med autoimmun pankreatitt (lymfoplasmacytisk skleroserende pankreatitt), og de mente at IgG4positive plasmaceller og CD4-positive T-lymfocytter infiltrerer diverse organer ved denne tilstanden. Karakteristiske histopatologiske funn er tette lymfoplasmacytiske infiltrater med økt andel IgG4-positive plasmaceller, fascikulær (storiform) fibrose, oblitererende flebitt og vanligvis også lett til moderat eosi- 

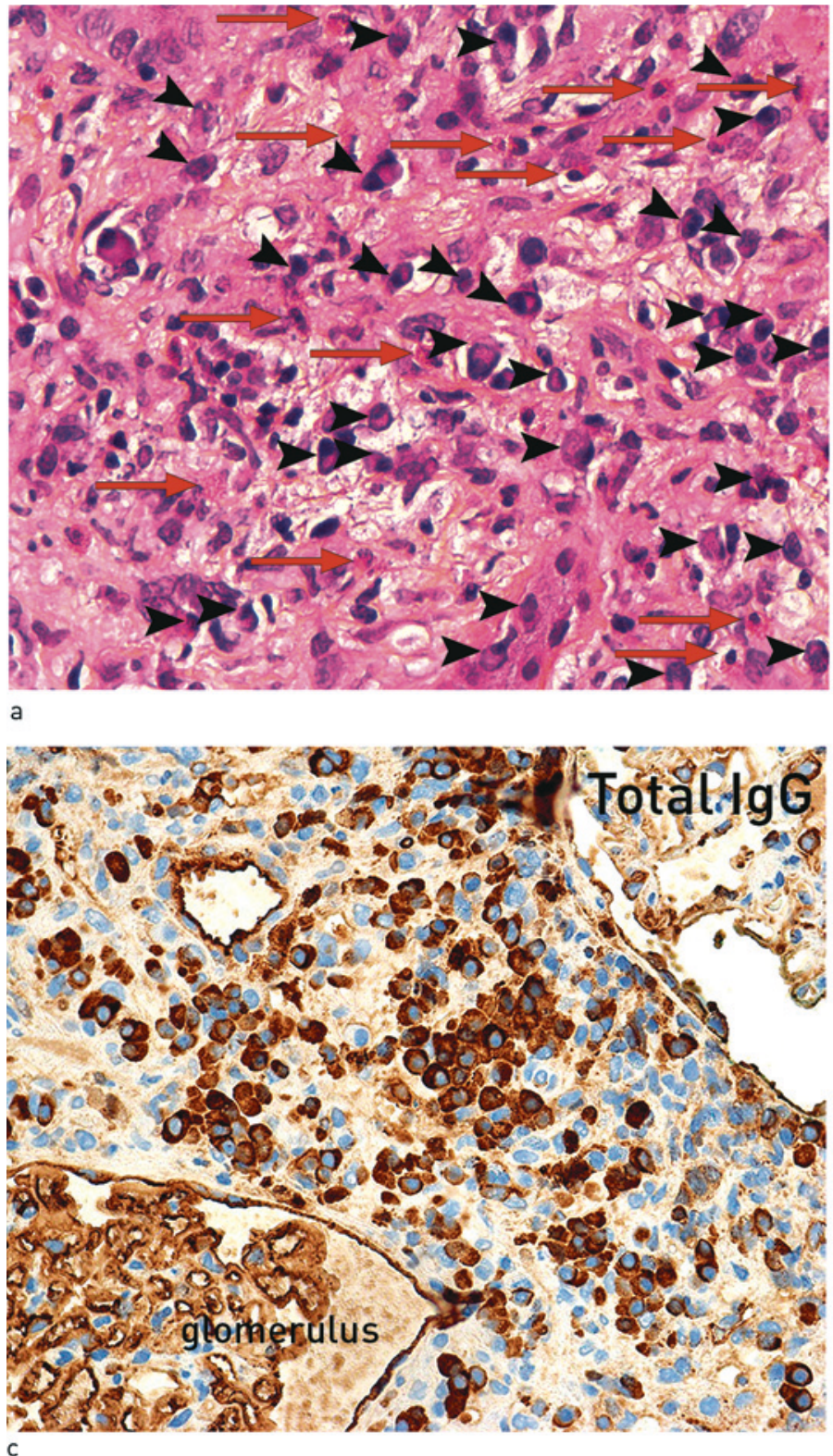

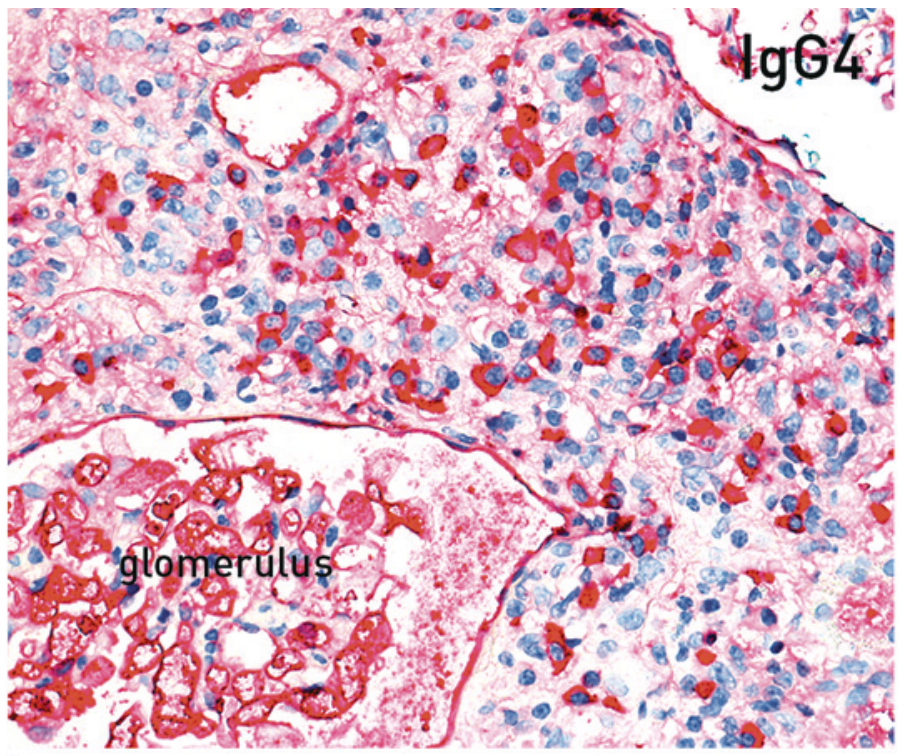

b

Figur 2 al Nyrebiopsien viste interstitiell nefritt med tallrike plasmaceller (sorte pilhoder) og eosinofile granulocytter (røde piler). $600 \times$ forstørrelse. b) og c) Immunhistokjemisk undersøkelse for IgG4 (rød farge) og total IgG (brun farge) viser økt mengde lgG4-positive plasmaceller i det interstitielle betennelsesinfiltratet. $400 \times$ forstørrelse nofili. De antatt vanligste manifestasjonene er - etter autoimmun pankreatitt - kolangitt, kolecystitt, sialadenitt, dakryoadenitt, inflammatorisk pseudotumor og retroperitoneal fibrose (14). Det så ut til at tilstanden var vanligst hos eldre menn og at behandling med steroider var effektivt (14).

Diverse tilstander omfattes nå av begrepet IgG4-relatert sykdom: Mikulicz' syndrom (affeksjon av spytt- og tårekjertler), Küttners tumor (affeksjon av submandibulære glandler), Riedels tyreoiditt, inflammatorisk pseudotumor (affiserer blant annet orbita, lunger og nyrer), retroperitoneal fibrose, periaortitt og -artritt med flere $(2,15)$. Biopsi av affiserte organer er viktigste diagnostiske hjelpemiddel, og selv om funn av forhøyet IgG4 i blod eller biopsert vev er nyttig diagnostisk, er dette ikke patognomonisk fordi forhøyet
IgG4 kan forekomme ved malignitet, lymfom og andre inflammatoriske tilstander (2, 15). IgG4/IgG-ratioen i vev er heller ikke tilstrekkelig for å stille diagnosen (2). Diagnostiske kriterier for IgG4-relatert Mikulicz' syndrom, pankreatitt og nyresykdom er etablert, så også for IgG4-relatert sykdom (13, 16). Det er usikkert om IgG4-antistoffene gir vevsdestruksjon eller om de kun ses som et resultat av et inflammatorisk stimulus (2).

Glukokortikoider anses som førstelinjeterapi, men enkelte pasienter responderer ikke, og tilbakefall ved dosereduksjon er vanlig (13). Azatioprin og mykofenolatmofetil brukes i disse situasjonene, men rituximabs evne til å mediere lysering av B-celler virker også lovende, og gode resultater er rapportert (13). Bortezomib, en proteasominhibitor som brukes ved multippelt mye- lom, er cytotoksisk mot plasmaceller og er også brukt i behandlingen av pasienter med IgG4-relatert sykdom (13).

Da vår pasient ble innlagt i nyremedisinsk avdeling, forelå det allerede opplysninger om at IgG var forhøyet. Videre var differansen mellom pasientens proteinuri og albuminuri såpass stor at proteinurien måtte skyldes et annet protein. Hadde vi hatt mer oppmerksomhet rundt dette, kunne diagnosen kanskje ha blitt stilt tidligere. Imidlertid var denne tilstanden nærmest ukjent for oss, og behandlingen ble den samme, med god og rask bedring som resultat.

Erfarne nefrologer kjenner godt til at steroider er effektive ved behandling av idiopatisk retroperitoneal fibrose (17), og muligens har mange av disse pasientene hatt IgG4-relatert sykdom $(18,19)$. Med økt oppmerksomhet 
om de tilstandene som omfattes av denne sykdommen, med IgG4 som fellesnevner, er det mulig at flere pasienter i fremtiden vil få korrekt diagnose og behandling.

Pasienten har gitt samtykke til at artikkelen blir publisert.

\section{Geir Christian Enli Mordal (f. 1975)}

er spesialist i indremedisin og i nyresykdommer og arbeider som overlege.

Forfatter har fylt ut ICMJE-skjemaet og oppgir ingen interessekonflikter.

\section{Clara Hammarström (f. 1975)}

er spesialist i patologi og arbeider som overlege. Hun har spesialkompetanse i nyrepatologi.

Forfatter har fylt ut ICMJE-skjemaet og oppgir ingen interessekonflikter.

\section{Tina Namtvedt (f. 1974)}

er spesialist i generell indremedisin og i nyresykdommer og arbeider som overlege.

Forfatter har fylt ut ICMJE-skjemaet og oppgir ingen interessekonflikter.

\section{Litteratur}

1. DeFronzo RA, Ferrannini E. Insulin resistance. A multifaceted syndrome responsible for NIDDM, obesity, hypertension, dyslipidemia, and atherosclerotic cardiovascular disease. Diabetes Care 1991; 14: 173-94.

2. Stone JH, Zen Y. Deshpande V. IgG4-related disease. N Engl J Med 2012: 366:539-51.

3. Rose NR. Predictors of autoimmune disease: autoantibodies and beyond. Autoimmunity 2008 41: 419-28

4. Liaño F. Pascual J. Epidemiology of acute renal failure: a prospective, multicenter, communitybased study. Kidney Int 1996; 50: 811-8.

5. Lameire N, Van Biesen W, Vanholder R. Acute renal failure. Lancet 2005; 365: 417-30.

6. Duong JK, Furlong TJ, Roberts DM et al. The role of metformin-associated lactic acidosis (MALA) Case series and formulation of a model of pathogenesis. Drug Saf 2013; 36: 733-46.

7. Bird HA, Esselinckx W, Dixon AS et al. An evaluFation of criteria for polymyalgia rheumatica. Ann Rheum Dis 1979; 38: 434-9.

8. Bitik B, Mercan R, Tufan A et al. Differential diagnosis of elevated erythrocyte sedimentation rate and $\mathrm{C}$-reactive protein levels: a rheumatology perspective. Eur J Rheumatol 2015; 2: $131-4$

9. Roufosse F, Weller PF. Practical approach to the patient with hypereosinophilia. J Allergy Clin Immunol 2010; 126: 39-44.

10. Hartmann A, Jenssen T, Julsrud J. Vanlige presentasjonsformer av nyresykdom. I: Hartmann A Jenssen T, Julsrud J. Nyremedisin - en praktisk veileder. Oslo: Gyldendal Akademisk, 2008: 13-58.

11. Saeki T, Ito T, Yamazaki H et al. Hypocomplementemia of unknown etiology: an opportunity to find cases of IgG4-positive multi-organ lymphoprolife rative syndrome. Rheumatol Int 2009; 30: 99-103.
12. Clarkson MR, Giblin L, O'Connell FP et al. Acute interstitial nephritis: clinical features and response to corticosteroid therapy. Nephrol Dial Transplant 2004; 19: 2778-83

13. Guma M, Firestein GS. IgG4-related diseases. Bes Pract Res Clin Rheumatol 2012; 26: 425-38.

14. Kamisawa T, Takuma K, Egawa $\mathrm{N}$ et al. Autoimmune pancreatitis and IgG4-related sclerosing disease. Nat Rev Gastroenterol Hepatol 2010; 7 $401-9$.

15. Kamisawa T, Zen Y, Pillai S et al. IgG4-related disease. Lancet 2015: 385: 1460-71.

16. Deshpande V, Zen Y, Chan JK et al. Consensus statement on the pathology of IgG4-related disease. Mod Pathol 2012; 25: 1181-92.

17. Harreby M, Bilde T, Helin P et al. Retroperitoneal fibrosis treated with methylprednisolon pulse and disease-modifying antirheumatic drugs. Scand J Urol Nephrol 1994; 28: 237-42.

18. Neild GH, Rodriguez-Justo M, Wall C et al. HyperIgG4 disease: report and characterisation of a new disease. BMC Med 2006: 4: 23

19. Khosroshahi A, Carruthers MN, Stone JH et al. Rethinking Ormond's disease: «idiopathic» retroperitoneal fibrosis in the era of IgG4-related disease. Medicine (Baltimore) 2013; 92: 82-91.

Mottatt 4.3. 2016, første revisjon innsendt 30.6. 2016, godkjent 6.9. 2016. Redaktør: Tor Rosness. 